\title{
Commemoration, Public History and the Professional Historian: An Irish Perspective
}

\author{
Gearóid Ó Tuathaigh \\ Professor Emeritus, NUI Galway, Ireland
}

Copyright (c) 2014 by Gearóid Ó Tuathaigh. This text may be archived and redistributed both in electronic form and in hard copy, provided that the author and journal are properly cited and no fee is charged for access.

\begin{abstract}
We live in time - it holds and moulds us - but I've never felt I understood it very well. And I'm not referring to theories about how it bends and doubles back, or may exist elsewhere in parallel versions. No, I mean ordinary, everyday time, which clocks and watches assure us passes regularly: tick-tock, click-clock. Is there anything more plausible than a second hand? And yet it takes only the smallest pleasure or pain to teach us time's malleability. Some emotions speed it up, others slow it down; occasionally, it seems to go missing - until the eventual point when it really does go missing, never to return. I'm not very interested in my schooldays, and don't feel any nostalgia for them. But school is where it all began, so I need to return briefly to a few incidents that have grown into anecdotes, to some approximate memories which time has deformed into certainty. If I can't be sure of the actual events any more, I can at least be true to the impressions those facts left. That's the best I can manage (Barnes 2012: 3-4).
\end{abstract}

I'm sure many of you will have recognized these lines from the opening of Julian Barnes's 2011 Booker Prize-winning novel, The Sense of an Ending. It would not have been especially difficult to find alternative, but equally apposite quotations, from several other recent, acclaimed novels: memory (and its relationship to History in effect, the different ways in which we deal with the past) has become something of a major preoccupation of writers in recent years. Perhaps it has always been so.

Nor is it simply a fashion among novelists or other 'creative' writers. The historian Richard White (American born, with maternal Irish ancestry), in his classic Remembering Ahanagran (1998) addressed directly the issue of how a trained historian, with a scruple for verifiable evidence, engages the stories (in effect, oral history) that his mother told of her youth and early upbringing in Ahanagran, a townland outside the village of Ballylongford in North Kerry, in the 1920s/early 1930s:
I once thought of my mother's stories as history. I thought memory was history. Then I became a historian, and after many years I have come to realize that only careless historians confuse memory and history. History is the enemy of memory. The two stalk each other across the fields of the past, claiming the same terrain. History forges weapons from what memory has forgotten or suppressed. Few non-historians realize how many scraps a life leaves. These scraps do not necessarily form a story in and of themselves, but they are always calling stories into doubt, always challenging memories, always trailing off into forgotten places.

But there are regions of the past that only memory knows. If historians wish to go into this dense and tangled terrain, they must accept memory as a guide. In this jungle of the past only memory knows the trails. ... [Turning to the mother's stories that he has 'researched', White continues] There is nothing my mother has told me that is without some basis in the past. But neither, at least in those cases where I can recover the historical scraps, is there a story 
that to a historian sifting through the evidence clearly happened as she remembers.

These stories and our collaboration have taught me much about the relation of history and memory. They have made me face in at least a small way the cruelty of recovering what memory seeks to bury or disguise. It is no wonder people prefer memory to history (White 1998: 4-5).

Memory is indeed a major preoccupation of our time. Professor Aidan Moran of UCD has spoken of our time as an 'age of reminders': with lists kept by people, in offices, in diaries, on mobile devices etc, to 'remind' them of things to do, appointments to keep, tasks to fulfil. This need for 'reminding' reflects, no doubt, the busy lives we lead and perhaps our distrust of our ability to remember everything on our crowded schedule. But, more darkly, the lengthening life expectancy of people (at least in the developed world) has brought with it anxieties about the failing or the loss of memory - senility, forms of dementia and Alzeimers - as an issue that has to be dealt with in our own personal lives or in the lives of family and friends.

It is hardly surprising; therefore, that individual memory has become such a central preoccupation of our times for a variety of commentators on the human condition. A recent study by Alison Winter, Memory: Fragments of a Modern History (2012), explores the controversies that have congealed around research on Memory - from the psychoanalytical approach to more recent neurophysiological studies.

Historians have been wrestling with this issue - the relationship between History and memory - for a very long time. For example, Moses Finlay reflecting on chronology, periodisation and the computistical notion of time, remarked many years ago:

Duration of time is not experienced as a measurable quantity, but as an associational or emotional quality... Memory leaps instantaneously to the desired point and it dates by association (1986: 23$)$.

The late Ralph Samuel (socialist founder of the History Workshop) more recently remarked that far from being merely a passive receptacle or storage system, an image bank of the past, memory is rather an active, shaping force, in that it is dynamic - what it contrives systematically to forget is as important as what it remembers and $\ldots$ it is dialectically related to historical thought, rather than being some kind of negative other to it. [Memory, then, is] historically conditioned, changing colour and shape according to the emergencies of the moment; that so far from being handed down in the timeless form of 'tradition', it is progressively altered from generation to generation. It leaves the impress of experience, in however mediated a way. It is stamped with the ruling passions of the time (in McBride 2001: 255).

Whatever about the complexity of the relationship between Memory and History for the individual, the concept of collective or social memory is still more problematic. Certainly, it cannot simply be understood as the sum (or the consensus) of a host of individual memories. Perhaps it is best considered, as Niall Ó Ciosáin has perceptively advocated, as

the framework(s) in which collectivities construct, embody and renew their shared sense of the past. These collectivities can range from small communities, whether urban or rural, through occupational groups, to nations or states. The most prominent studies of such memory ... reflect a growing awareness of the public and political uses of history in the creation or evolution of nation-states, national communities and national identities. The shared memory which underlies or is created by nations is manifested in public commemoration and monuments, in state institutions such as national museums, and in official histories (2001: 95-6).

One might add that at the sub-state or subnational level, such 'shared memory' of communities is also very frequently manifested in monuments and through various forms of commemoration.

The term 'public history' - the state of historical awareness among the general public, not specifically trained or educated in historical enquiry or exposition - is increasingly, and generally slightingly, used in various recent commentaries on the (dangerous) participation by professional historians in 'official' commemorations or the dissemination of historical explanation through popular or mass media.

The most severe version of the dangers for the professional historian of becoming involved in public history is that which sees the exercise 
of professional scruples (for evidence) by the professional historian as being constantly menaced by, if not inherently incompatible with an involvement in the main domains of public history. Thus John Regan (2012: 11) recently claimed that:

we need to appreciate the tensions existing between what historians call 'the two histories'. One of these is the historical research written by professional and some independent scholars. This follows recognized procedures. ... Two principles must be applied simultaneously if historical research is to be effective. First, the evidence from which interpretations are drawn must be verifiable. Typically, historical research is footnoted with reference to sources so that others may check if they choose. The second depends on the first. Historical research must be critically engaged and interpretations tested against the evidence alongside existing interpretations...

The second of the two is what some call 'public history', produced for mass consumption. Public history is seen everywhere - in the media, newspapers, films, television documentaries and museums. Public history reaches general audiences and attempts to educate - and entertain - and promotes ideas of 'national identity' and 'heritage'. Historians mostly agree that public history can be a good thing - and it can be lucrative too.

Public histories popularize the past, but they are conditioned by the needs of the present. They may want to win votes for the government or loyalty for a cause, or just pay their way as commercial ventures. Public histories pander to the expectations of mass audiences, whereas historical research is more interested in the past for its own sake. And public histories cannot easily be held to account - television documentaries have no footnotes. But - and this is our significant problem - to produce something acceptable to the present, public histories are always tempted to simplify, even to distort the past.

\section{Historical awareness and the practice(s) of History}

It is probably the case that most modern professional historians, in 'open societies' take their cue from nineteenth-century historicism, which taught that the past should be studied on its own terms, 'as it actually was' (von Ranke).

Historical awareness (as understood by historicists) is, as John Tosh (2006: 1-12) usefully reminds us, constituted by several fundamental principles. First, and crucially, it involves the recognition of difference between our own time and an earlier time (however recent). This 'otherness' of History relates not just to circumstances or conditions, but to attitudes, beliefs, mentalité. Secondly, in order to make sense of this 'otherness', the historian seeks to contextualize events/episodes in the Past, provide the 'particularity' of context within which an historical event/process can be made intelligible. Thirdly, we must acknowledge that historical awareness for the historian also demands that we address the "historical process - the relationship between events over time which endows them with more significance than if they were viewed in isolation." That is to say, History is not a series of discreet, 'strange', rigorously contextualized episodes: it requires the narrative of change over time - the interconnectivity of episodes/events over a period of time - to render it persuasive.

The key differences between the historical awareness of the 'trained' historian and popular awareness of history, may be described as differences of assumption and approach: "Professional historians insist on a lengthy immersion in the primary sources, a deliberate shedding of present-day assumptions, and a rare degree of empathy and imagination. Popular historical knowledge, on the other hand, tends to a highly selective interest in the remains of the past, is shot through with present-day assumptions, and is only incidentally concerned to understand the past on its own terms."

This classic Rankean version of the (dispassionate) professional study of the Past (that distinguishes 'History' from nostalgia or a morality tale) may indeed still be the dominant understanding, the conventional wisdom, within the historical profession in the 'open societies' of the West. But it is important to point out that, in recent decades (and responding to powerful currents in critical or cultural theory), a considerable cohort of historians has become more self-aware of the intellectual procedures by which historians formulate the terms of their enquiry and of the more formal dimensions of history-writing (its very literariness).

But even if we allow the more conventional Rankean version of 'professional History' to stand, this does not require or compel us to concede that it can or should be hermetically 
sealed from 'public history'. Indeed, I believe this notion of an incompatibility between professional and public history to be fundamentally misconceived.

Firstly, we may note in passing that Regan is silent (as are others) on a key site for the production and critiquing of versions or varieties of public history widely current in the 'open' society: the education system and the history that is 'taught' in our schools. Academic historians are routinely involved in determining or advising on curriculum content; in the training of teachers, in providing or contributing to in-service courses.

But even in the 'domains' of public history cited as 'suspect' by Dr Regan (media, films, television documentaries, newspapers and museums), we need to ask: what exactly is it that fatally contaminates the historian's vocation through involvement in such media of public history? Do historians enter into such public history in bad faith, as it were? Is it the contention that the audience for public history is inherently uncritical, lacking the discrimination - with regard to evidence and interpretation - that professional history demands? Or, is the charge that popular media (such as television) inevitably over-simplify complex situations and arguments?

I find none of these 'assumptions' altogether satisfactory or persuasive. Is it imaginable that the Director of a National Museum would ignore or suppress new findings in relation to exhibits or artifacts on display? Or, on a radio talk or public lecture, would a historian distort or ignore evidence, in order to please an audience or placate a sponsor (including the government)? Or, even in the area that is often deemed most problematic - television history, is it suggested that a professional historian would set out, deliberately, to distort the evidence or the interpretation, in order to win support (for a party or a cause), or to achieve commercial success, at the expense of engaging scrupulously with the historical data and methodology?

Posed in rhetorical terms like this, of course one expects a rising chorus of 'never' to each of the questions! But, let me hasten to add, that there are indeed hazards to which the historian needs to be alert when participating in the forum of public history. It behoves professional historians to understand the various media that they use to communicate their understanding of historical episodes, events or movements (based on responsible, rigorous research, be it their own or that of other scholars. The 'forms' of historical writing appropriate to radio talks or reviews, television documentaries, to written articles or reviews in academic publications, in higher journalism or in the popular press, are all very different. But scholars are generally aware of this: they make these kinds of distinctions all the time. But no medium requires the historian to abandon the fundamental, professional obligations to attend scrupulously to the evidence.

The idea that there ought to be some kind of cordon sanitaire between 'professional' history-writing (hermetically sealed in its monk's cell, in virtuous pursuit of truth) and a 'public history' for the great unwashed (inherently corrupting in its demands and procedures) is, it seems to me, an unrealistic, not to say, mistaken view. Participation in 'public history' requires historians to become not only literate, but educated, in the various forms and media through which 'public history' is communicated. What it does not require nor should it ever - is the kind of deliberate, purposeful unhistoricity that, in a fundamental sense, is a betrayal of their discipline. Suppressing uncomfortable evidence, distorting it, forcing it into moulds in order to gain votes for a party or a cause (however morally worthy - reconciliation, the peace process etc.), to entertain the unthinking masses, or to line the pockets of television companies or indeed their own pockets, is, in my book, no kind of history at all, professional or public.

\section{Commemorations}

This is especially pertinent to the vexed issue of the role of historians in Public Commemoration; never more so than at the present time, as we in Ireland are embarked on a decade or so of notable anniversaries (overwhelmingly centenary anniversaries of the revolutionary decade 1912-22). Commemorations are a large subject, and there basic questions to be asked about any commemoration, but in particular about public commemorations. These questions are not peculiar to Ireland. Thus, historians and intellectuals within the liberal states of the West have been accused of allowing themselves to be 'co-opted' into state-selected 
anniversaries and commemorations, as a consequence of the state having become the main funder of cultural, educational, intellectual institutions (including the universities) for the intelligentsia, and the main source of cultural budgets:

Schools, universities, theatres, museums, literary organizations and cultural institutes abroad thrive on state funding. In return for investing in culture, state agencies expect these activities to enhance national identity. Intellectuals who get paid to organize and attend anniversary commemorations acquiesce in becoming retainers of the state. The device that more than any other eases such dependency is the cult of anniversaries. It mediates between the state's interest in promoting national identity and intellectuals' interest in playing a public role. ... [Thus] a kind of commonwealth of Anniversaries has emerged in present-day Europe, whereby intellectuals accept subsidies for articulating national values, even when they disagree with much of what is done in the name of those values (Johnston 1991: 45-46).

Here, it may be useful simply to remind ourselves of some of the many varied categories and forms of commemoration which are part and parcel of all our lives.

1. At the most personal level, we might mention those long columns of 'remembrance' or anniversary death notices which feature in the local papers in Ireland every week.

2. Then there is the ever-burgeoning calendar of local literary, musical or folk-schools or éigsí, commemorating the life, the achievements or the legacy of writers, musicians or artists who were born or lived for a time or worked or died or were buried in a particular place.

3. The commemoration of specific events in History - a battle, a treaty, an act of parliament, a city charter, the birth or death of a notable figure in national or international events, the 'first' journey (crossing, flight) or discovery/invention; the first (or indeed the last) performance of a particularly significant feat). These commemorations may take the form of the unveiling of a plaque or public monument; the holding of commemorative religious services; a special lecture in a public place, or a series of talks/lectures or a documentary on radio; a television programme - a documentary; the commissioning of a musical composition/art work; various forms of public spectacle - drama, pageant, parades, street-events, a dinner; special publications (centenary histories, pictorial records etc.).

These - no doubt familiar - forms of commemoration are, of course, generally undertaken by individuals and groups acting in a voluntary capacity. Such groups may - under certain circumstances - claim to be (and in some measure may in fact be) representative of a larger community or, as they might put it, representative of 'the people' (of the village, parish, town community).

But, of course, there are also commemorations which are sponsored, organized, endorsed or actually 'staged' by the State itself. These are often referred to as 'official' or State commemorations. They may take many forms, e.g.:

- the issuing of a commemorative stamp,

- the laying of wreaths by government ministers or by the President, at a significant public place,

- $\quad$ events held at national monuments - with permission granted to Defence Forces to be present and participating in such events,

- an official state presence at special religious services

This short, selective inventory of commemorations with which all readers will be familiar is offered simply in order to remind ourselves of just how pervasive is this imperative to commemorate in our culture (as indeed it is in many, perhaps all, human societies). But, we also know that there are commemorations that are contentious and controversial, contested and divisive. This should at least alert us to the fact that commemorations are not simply the innocent public version of 'calling things to mind' in private or in a family setting.

It is not difficult to cite recent examples of controversy and contention regarding commemorations. The manner in which the sesquicentenary of the Great Famine was commemorated in the later 1990s (from 1995) exited some controversy: the issue of responsibility and atonement was raised, with Prime Minister Tony Blair making apology for the shortcomings of British policy at the time of the Famine, and unavailing calls made for an 
apology from the Queen. This kind of issue is not exclusively Irish, of course: it crops up regularly. For example, there are regular calls by WW2 prisoners of war on Japan to apologize for its wartime crimes and to make some reparation: but, invariably moral equivalence issues arise, with references to Pearl Harbour being answered by reference to Hiroshima and Nagasaki.

Again, nearer home, the bicentenary of the 1798 rebellion in Ireland provoked debate and controversy, not least because of the sensitivity of the event - its legacy and the implications of any kind of commemoration - for the delicate talks then going on in Northern Ireland as the 'peace process' approached end-game. The issue of how to 'handle' public commemoration of the complex legacy of 1798 presented a challenge to the Irish government and to the wider community. ${ }^{1}$

Before probing a little further what these controversies may tell us about commemorations and about ourselves, perhaps it would be better to state clearly the key questions that I believe ought to be asked regarding any kind of public commemoration/commemorative event. These are:

Firstly, who is doing the commemorating? Secondly, what is the stated reason for the commemoration, the declared purpose or aim?

Thirdly, what exactly is being commemorated? Fourthly, what form(s) is the commemoration to take?

Fifthly (and lastly), why now? - the issue of timing or frequency.

Of course, there has been a growing interest in, and consideration of questions of this kind, by historians and others, in recent years. Beginning with the work of Pierre Nora, that of Jay Winter in the Anglophone world, and, in the Irish context, Brian Walker, Ian McBride and a host of more recent studies, explorations of the relationship between history, commemoration and memory is becoming a growth industry. Some of the findings of these studies in the Irish context are full of interest; as they relate to the changing significance (and forms) of, for example, St Patrick's Day commemorations over recent centuries; or of the history of commemoration of the Battle of

1. See R.F. Foster, The Irish Story (2001: 211-34) for an astringent view of this episode. the Boyne ('the Twelfth'); or again, of Armistice Remembrance Day (Sunday) ceremonies; or, finally, of the commemorations that marked different anniversaries of the 1916 Rising.

What has emerged from this consideration of even these 'best known' of Irish public commemorations is how 'recent' in origin some of them are (providing rich examples of the 'invention of tradition'); how their significance ('meaning') has been, and, in some instances, continues to be contested; and how matters of ownership, motive and form are central to understanding their impact on and their importance for different groups within Irish society.

What we need to return to, therefore, in the Irish experience, as in all other cases, is the basic issue of why do certain people (or groups of people - including Governments, of course) decide to commemorate particular events, episodes, people from the past? What needs do such commemorations serve? Certainly, we may say at once that the needs served must be the needs of the living, that is, of those doing the commemorating: after all, the needs of the dead are past our knowing. Our needs, however, are a different matter.

In the light of insights from psychology and psychoanalysis, it has been suggested (by novelists, cultural commentators and historians) that commemoration - or, 're-memoration' as the novelist Toni Morrison has called it - is a way for people who have suffered major trauma in their history to come to terms with that trauma and that history; particularly if the memory of it has been so painful and problematic that it has been concealed or suppressed for some time. This particular function (the broadly therapeutic, if you like) of commemoration is sometimes cited in discussions of the Holocaust, and indeed it was frequently cited with regard to the various commemorations during the later 1990s of the $150^{\text {th }}$ anniversary of the Great Famine. A healing act of recovery was facilitated by collective commemoration, or so it was argued: there was much talk of 'closure', of a certain kind of grief.

Yet, whatever the therapeutic effects of commemoration in respect of major traumatic episodes in a people's history, most of the events which are the subject of public commemoration are not of this kind. But what is incontestable is that 'public' commemoration 
(however modest in scale, makeshift in execution or seemingly spontaneous in inspiration) is always an act of conscious, deliberate, purposeful cultural construction. It involves selection and omission, assertion, affirmation and, of course, presentation. In concept and form it is a deliberate creation, and it meets (or is intended to meet) the specific, if often varied needs of its creators.

It is precisely because commemorations are such creations that they are frequently contested - and contested for a variety of reasons. One doesn't need to look far for illustrations; in a deeply- divided society like Northern Ireland, contested meanings and competing needs apply to virtually all public commemorations. The Parades Commission, for example, is constantly presented with these recurring questions: what exactly is being commemorated? What is the purpose of the commemoration, what form will it take? What needs - or, more pointedly, whose needs - are being met? The forms of the commemoration the particular site for a monument or a mural, the particular routes chosen for the parade rituals of commemoration, and the theatrical props, emblems or symbols deployed in the public demonstration - all have significance, all are implicated in the commemoration's contested legitimacy. They raise questions regarding the 'real' (latent, as distinct from the manifest) purpose of such parades or other rituals, and of the real needs being met. Parades, murals, flags and emblems, streetnames: these are all 'read', in a divided society, as forms of assertion and invasion rather than as innocent rituals of communal identity and remembrance.

A different kind of contestation arises where there are competing needs in respect of the same 'commemorative event'; what we might describe as contested ownership of the same cultural resource/asset. A good example of this is Bodenstown: where rival republican groups have for decades sought to 'commemorate' Wolfe Tone, as a way of establishing their own political pedigree or credentials, of affirming their continuity with and succession from the Wolfe Tone republican separatism of the 1790s.

The 'ownership' of commemorations for specific political purposes is not, of course, an exclusively Irish habit, any more than any other aspect of the commemorative agenda that we've been addressing. Consider, for a moment, the curious - not to say bizarre - example of the Primrose League of late Victorian England. Indeed, as symbols of commemoration, flowers have been quite potent (and often ideologically pungent) in modern Ireland. The Easter Lily, for example, signals republican credentials, while the annual wearing of the poppy in November (a project of the British Legion in many countries) reminds us of the fact that changing needs and circumstances regularly alter the significance - the meaning and form of symbols in commemorations.

The changing significance of historical events (for commemorative purposes) can be seen in the history of many countries. For example, Bastile Day wasn't always a comfortable 'bonding' day for all of the French. We know that the battle of the Boyne was not in fact regularly celebrated until the 1790s, at the time of the foundation and early rise of Orangism. And the point of historical interest becomes, what particular circumstances (what particular needs) of the 1790s gave rise to the beginnings of such commemorations? What new circumstances/needs in the future may see its significance and its form change again?

As to the changing frequency of commemorations of the same event, this also has attracted attention, and a little controversy, in recent years. For example, the centenary of the start (in 1845) of the Great Famine was not marked in 1945 with anything like the spate of public (including State-sponsored) commemoration, as that which marked the sesquicentenary in 1995. The national mood had changed by the 1990s: a confident and prosperous Ireland could more easily 'deal' with the Famine in its time and with its legacy; and the event had also acquired a wider significance in the public debate on global food scarcity and entitlements.

The $50^{\text {th }}$ anniversary of the 1916 Rising was the occasion for major state and public commemoration in 1966 (sometimes denounced as 'triumphalist' and 'provocative'). In 1991, on the $75^{\text {th }}$ anniversary, there was general unease at government level as to whether there should be an official commemoration at all, and, if so, what should (indeed what could) it safely be? By 2006, with the Peace process in the Northern seemingly well bedded-in, the government in Dublin felt safe in re-instating a military parade to commemorate the $90^{\text {th }}$ anniversary of the 
Rising. ${ }^{2}$

It will be clear, I trust, from what I have been considering here, that the relationship between the public commemoration of events and of people in the past and the kind of evidencebased research and reflectively comparative analysis and interpretation of these events with which the professional historian is ordinarily occupied, is a complex relationship. Acts of commemoration are acts of appropriation, exclusion, reclamation, selective and everchanging. The key factor in this process - the key variable, if you wish - resides in the changing needs at any moment in time of the 'present' generation - the generation doing the commemorating.

As for the relationship of professional historians to public commemorations, I think it is virtually inevitable (certainly highly likely) that, in respect of discussion, organization and presentation of public commemorative events, historians may prove to be difficult people, potentially the spoilsports or party-poopers of the proposed events. The reasons for this, I hope, will already be obvious to you: they may be easily summarized.

Historians, professional historians, are every bit as much people of their own generation as any other body of citizens. They cannot escape, any more than anybody else, sharing in the assumptions, concerns, preoccupations of their own time and place. Their view of the past will, inevitably, be present-centred, to some degree. But, if they are good historians, they will have developed a particular reflexivity (intellectual as well as emotional and imaginative) in dealing with the past. They will be more aware

2. Recent contributions to the burgeoning field of '1916 historiography' include Mary Daly and Margaret O'Callaghan (eds), 1916 in 1966: Commemorating the Easter Rising (Dublin: Royal Irish Academy, 2007); Rebecca Graff-McRea (ed), Remembering and Forgetting 1916: Commemoration and Conflict in Post-Peace Process Ireland (Dublin: Irish Academic Press, 2010); Roisín Higgins, Transforming 1916: Meaning, Memory and the Fiftieth Anniversary of the Easter Rising (Cork: Cork UP, 2012); Mark McCarthy, Ireland's 1916 Rising: Explorations of History-Making, Commemoration \& Heritage in Modern Times (Farnham: Ashgate Publishing Company, 2012).
- more alert to the perils - of dealing with the contemporaneity of their own perspective; they will be more deliberately self-conscious about the differences between 'our' view of things and that of past generations. They will have a specifically developed scruple for evidence (including a sense of the changing meaning of words, concepts and rituals). They will not only seek to establish accurately 'what happened' (based on the surviving record of verifiable, factual data), but will also seek to explain what happened and how it happened (as it did, when it did), by contextualizing events, episodes, institutions, attitudes and personalities - as they have changed over time.

This habit of 'contextualizing' is something which we all do: it is such a pervasive aspect of public commentary in an open society, that we scarcely notice it. The act of 'placing' an event or incident in a rational, evidence-based, framework of explanation (causes/ circumstances/consequences), so as to make sense of the event, is part of the everyday culture of public commentary in an open society. Historians do this, however, with a particular rigour in the evaluation of evidence and in the presentation of an explanation. This has crucial implications for how historians relate to public commemorations. In respect of historic events which have been selected for public commemoration because their 'meaning' or 'significance' is perceived as meeting, in some affirmative sense, the 'needs' of a community, there is always the possibility that historians will come up with new 'facts' which may disturb that meaning or significance, or will contextualize the event in such a way as to cloud, to question or even to subvert the 'perceived meaning' which it seemed to have, at least for those who embarked upon the commemoration in the first place. To put it another way, commemorations are particular cultural events quarried from the protean resource of public history. Historians are part of that public, and, in an open society, are implicated in complex ways in the ways that public history is generated, disseminated and critiqued. By training and vocation, they will regularly challenge some cherished nostra of public history. This is why historians themselves are often nervous and uneasy guests at the public party that is 'an official historical commemoration'. It is also the reason why those 
organizing such public parties would do well to be a little nervous about inviting them.

Finally, there is a certain urgency to our consideration of these various aspects of public history in Ireland. We have entered upon a period in our history, where the commemoration of the centenary of a series of notable, indeed fateful, events in the recent history of Ireland (and of the world) will dominate public discourse at all levels. No one can doubt that the manner in which these centenary anniversaries are 'addressed' within Irish society (north and south) may have serious consequences for political and social life in contemporary Ireland.

All of the 'uses' of the Past that we have noted (or that we can imagine) will be deployed by various parties seeking a commanding position in the ideological and political debate on the future direction of Irish society, and accordingly, seeking the ideological and political 'capital', of the pivotal events of 1913, 1914, 1916 etc. and what they might signify for the Ireland of today. Historians will be involved, in various ways, in this rich feast of 'public history'. I do not see this involvement as necessarily a form of academic apostasy or betrayal. But it will present challenges and dilemmas. As professional historians step from their comfort zone of 'academic history' to the more clamorous world of public history, they must be mindful of the demands and dangers of the public media in which they will be expected to perform, and they must retain at all times the severest sense of obligation to the established rules of their profession as academic historians.

\section{Works Cited}

Barnes, Julian. 2012. The Sense of an Ending. London: Vintage Books

Finley, Moses I. 1986 [1975]. The Use and Abuse of History, London: The Hogarth Press.

Johnston, William M. 1991. Celebrations: The Cult of Anniversaries in Europe and the United States. New Brunswick, NJ and London: Transaction Publishers.

McBride, Ian (ed.). 2001. History and Memory in Modern Ireland, Cambridge: Cambridge U.P.

Ó Ciosáin, Niall. 2001. "Famine memory and the Popular Representation of Scarcity", Ian McBride (ed.), History and Memory in Modern Ireland, Cambridge: Cambridge U.P., 95-117.

Regan, John M. 2012. "Dr Jekyll and Mr Hyde: the two histories”, History Ireland, vol.20, no.1. January/February.

Tosh, John (with Seán Lang). 2006. The Pursuit of History, London: Longman.

White, Richard. 1998. Remembering Ahanagran, New York: Hill and Wang.

Winter, Alison. 2012. Memory: Fragments of a Modern History. Chicago: University of Chicago Press.

Received $15^{\text {th }}$ November $2013 \quad$ Last version $18^{\text {th }}$ November 2013

Gearóid Ó Tuathaigh is Professor Emeritus of History and former Vice-President at NUI, Galway. His numerous publications relate mainly to Irish and British history of the nineteenth and twentieth centuries. A regular commentator on aspects of public policy, he is currently a member of the Council of State. 